\title{
In vitro activity of three commercial bacteriophage cocktails against multidrug- resistant Escherichia coli and Proteus spp. strains of human and non-human origin
}

Odette J. Bernasconi ${ }^{\mathrm{a}, \mathrm{b}}$, Valentina Donà ${ }^{\mathrm{a}}$, Regula Tinguely ${ }^{\mathrm{a}}$, Andrea Endimiani ${ }^{\mathrm{a}, *}$

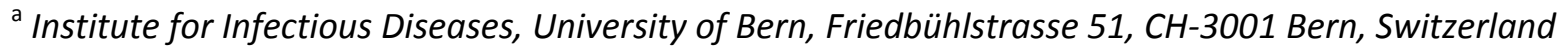

${ }^{\mathrm{b}}$ Graduate School of Cellular and Biomedical Sciences, University of Bern, Bern, Switzerland

ARTICLE INFO

Article history:

Received 13 December 2016

Accepted 18 December 2016

Keywords:

Bacteriophage

Escherichia coli

Proteus spp.

ESBL

AmpC

Carbapenemase

* Corresponding author. Tel.: +41 316328 632; fax: +41 316328766.

E-mail addresses: andrea.endimiani@ifik.unibe.ch; aendimiani@gmail.com (A. Endimiani). 


\section{ABSTRACT}

Objectives: Bacteriophages may represent a therapeutic alternative to treat infections caused by multidrug-resistant (MDR) pathogens. However, studies analysing their activity against MDR Enterobacteriaceae are limited.

Methods: The in vitro lytic activity of three commercial bacteriophage cocktails (PYO, INTESTI and Septaphage) was evaluated against 70 Escherichia coli and 31 Proteus spp. of human and non-human origin. Isolates were characterised by phenotypic and genotypic methods and included 82 MDR strains [44 extended-spectrum- $\beta$-lactamase (ESBL)-producers (18 CTX-M-15-like, including ST131/ST648 E. coli); 27 plasmid-mediated AmpC $\beta$-lactamase (pAmpC)-producers (23 CMY-2-like, including ST131 E. coli); 3 $\mathrm{ESBL}+$ pAmpC-producers; and 8 carbapenemase-producers]. Phage susceptibility was determined by the spot test.

Results: Escherichia coli susceptibility to PYO, INTESTI and Septaphage was $61 \%, 67 \%$ and $9 \%$, whereas that of Proteus spp. was $29 \%, 39 \%$ and $19 \%$, respectively. For the subgroup of ESBL-producing $E$. coli/Proteus spp., the following susceptibility rates were recorded: PYO, 57\%; INTESTI, 59\%; and Septaphage, $11 \%$. With regard to pAmpC-producers, $59 \%, 70 \%$ and $11 \%$ were susceptible to PYO, INTESTI and Septaphage, respectively. Five of eight carbapenemase-producers and three of four colistinresistant $E$. coli were susceptible to PYO and INTESTI.

Conclusions: This is the first study analysing the activity of the above three cocktails against wellcharacterised MDR E. coli and Proteus spp. The overall narrow spectrum of activity observed could be related to the absence of specific bacteriophages targeting these contemporary MDR strains that are spreading in different settings. Therefore, bacteriophages targeting emerging MDR pathogens need to be isolated and integrated in such biopreparations. 


\section{Introduction}

Treatment of infections caused by multidrug-resistant (MDR) Enterobacteriaceae represents a continuous challenge. These pathogens are frequently resistant to extended-spectrum cephalosporins owing to the production of extended-spectrum $\beta$-lactamases (ESBLs) and/or plasmid-mediated AmpC $\beta$ lactamases (pAmpCs) [1-3]. Moreover, even the last therapeutic options, namely carbapenems and polymyxins, are under attack due to the spread of carbapenemase- and/or MCR-1/2-producing strains, respectively $[4,5]$.

In this overall scenario, the use of bacteriophages (highly species-specific self-propagating viruses that can infect and lyse bacteria) could represent a valid therapeutic alternative to treat infections caused by extended-spectrum cephalosporin- and/or carbapenem-resistant Gram-negative pathogens $[6,7]$. Bacteriophage therapy is part of the standard medical practice in the former Soviet Union countries. In contrast, in Western nations the use of phage therapy is unfamiliar and this has generated a lack of clinical studies analysing the efficacy of this possible alternative therapeutic approach $[6,7]$. Therefore, most of the available scientific literature in English presents data obtained only with animal models. For instance, bacteriophage treatment was effective in in vivo models with ESBL-producing Escherichia coli, including those belonging to the hyperepidemic clone of sequence type 131 (ST131) [8-10].

Whilst data regarding the in vitro activity of bacteriophages against E. coli and Staphylococcus aureus are available, studies analysing their activity against large collections of MDR Enterobacteriaceae are very limited. Fitzgerald-Hughes et al. showed that $89 \%$ of human ESBL-producing $E$. coli isolates were susceptible to at least one of four bacteriophage cocktails [11]. However, strains were defined as ESBLproducers only using the phenotypic European Committee on Antimicrobial Susceptibility Testing (EUCAST) criteria; moreover, pAmpC- or carbapenemases-producers were not tested and multilocus sequence typing (MLST) was not performed to define the ST [11]. In another study, Sybesma et al. assessed the susceptibility of ESBL-producing E. coli and Klebsiella pneumoniae strains, all isolated from patients suffering from urinary tract infection (UTI), to four Georgian bacteriophage cocktails and several mono-phage preparations [12]. Their results showed great variability, with lytic activity ranging from $66 \%$ to $93 \%$ for $E$. coli and from $0 \%$ to $100 \%$ for $K$. pneumoniae [12]. Consistent results were also obtained by Gundogdu et al. who recently tested ESBL-producing $E$. coli from patients' blood and urine samples [13]. However, for these two latter studies, ESBL production was only phenotypically defined and no information on the ST or resistance gene profiles of the bacteria was presented $[12,13]$.

To our knowledge, the activity of commercially available bacteriophage cocktails against well-defined MDR E. coli strains of animal and food origin has never been described. In the same context, data regarding Proteus spp. isolates detected in different settings are completely lacking. Therefore, in this work we aimed to assess the lytic effect of three commercial bacteriophage preparations, all available to 
the public in Georgia, on a large collection of well-characterised human and non-human E. coli and Proteus spp. strains.

\section{Materials and methods}

\subsection{Bacteriophage cocktails}

Three commercially available bacteriophage cocktails produced by Georgian institutions located in Tbilisi were tested. According to the manufacturers, they are all sterile-filtrate phage lysates of different bacterial species as listed below. The preparation lot numbers implemented during the present work are indicated in parentheses, along with the declared phage concentration specified by the provider.

\subsubsection{PYO Bacteriophage}

PYO Bacteriophage (lot \# M1-801; Eliava BioPreparations, Tbilisi, Georgia) targets E. coli, Proteus mirabilis, Proteus vulgaris, Pseudomonas aeruginosa, Staphylococcus spp. and Streptococcus spp. The specified concentration was $1 \times 10^{5-6}$ plaque-forming units (PFU)/mL.

\subsubsection{INTESTI Bacteriophage}

INTESTI Bacteriophage (lot \# M2-801; Eliava BioPreparations) targets E. coli, P. mirabilis, P. vulgaris, Salmonella Paratyphi A and B, Salmonella Typhimurium, Salmonella Enteritidis, Salmonella Choleraesuis, Salmonella Oranienburg, Shigella flexneri, Shigella sonnei, Shigella newcastle, P. aeruginosa, Staphylococcus spp. and Enterococcus spp. The specified concentration was $1 \times 10^{5-6} \mathrm{PFU} / \mathrm{mL}$.

\subsubsection{Septaphage}

Septaphage (lot \# 01.05.15; Biochimpharm, Tbilisi, Georgia) targets different serogroups of enteropathogenic E. coli, Proteus spp., S. Paratyphi A and B, S. Typhimurium, S. Choleraesuis, $S$. Oranienburg, S. Enteritidis, S. flexneri (serogroups 1, 2, 3, 4 and 6), S. sonnei, P. aeruginosa, Staphylococcus spp. and Enterococcus spp. The specified concentration was $1 \times 10^{5} \mathrm{PFU} / \mathrm{mL}$.

All three phage cocktails are available to the public without prescription in Georgia. In particular, PYO is used to treat purulent skin, surgical, oral, enteral and gynaecological infections, whereas INTESTI and Septaphage are implemented for intestinal infections. 


\subsection{Bacterial collection and characterisation}

The in vitro activity of the above three phage preparations was evaluated against a collection of 70 wellcharacterised and contemporary E. coli isolates of human $(n=31)$, animal $(n=22)$ and food $(n=12)$ origin as well as 5 laboratory controls (Table 1$)$. Overall, the majority of strains $(43 / 70 ; 61 \%)$ were detected in the last 5 years $(2015, n=23 ; 2014, n=2 ; 2013, n=3$; and 2012, $n=15)$. Most strains were previously characterised by phenotypic [minimum inhibitory concentration (MIC) determination using microdilution Trek panels] and genotypic [CheckPoints CT103 or CT103XL microarray, PCR/sequencing for bla genes, plasmid content by PCR-based replicon typing (PBRT) and MLST] methods [1,3,5,14-18]. In particular, the collection included 37 ESBL-producers (18 CTX-M-15-like), 21 pAmpC-producers (17 CMY2-like), $2 \mathrm{ESBL}+$ pAmpC-producers, and 7 carbapenemase-producers (4 NDM, 2 OXA-48 and 1 IMP). Four colistin-resistant strains were also included, one of which carried the $\mathrm{mcr}-1$ resistance gene [5].

In addition, 21 well-characterised $P$. mirabilis of human $(n=18)$ and food $(n=3)$ origin [3] were tested, along with $10 P$. vulgaris responsible for human bacteraemia at Bern University Hospital, University of Bern (Bern, Switzerland). Overall, 7 ESBL-producers (4 VEB, 2 TEM and one CTX-M), 6 pAmpC-producers (all CMY-2), 1 with CTX-M-9-/CMY-2-like and 1 carbapenemase (NDM)-producer were tested. Most strains $(27 / 31,87 \%)$ were detected in the last 5 years $(2016, n=9 ; 2015, n=5 ; 2014, n=6 ; 2013, n=3$; and $2012, n=4$ ) (Table 2).

Species identification of all E. coli and Proteus spp. strains was done using matrix-assisted laser desorption/ionisation time-of-flight mass spectrometry (MALDI-TOF/MS) (Bruker Daltonics, Leipzig, Germany). Strains were defined as MDR according to Magiorakos et al. [19].

\subsection{Susceptibility to bacteriophage cocktails}

Phage susceptibility was determined by implementing the spot test with Double Agar Overlay Plaque Assay [20]. Briefly, a $10 \mu \mathrm{L}$ loop of fresh overnight culture was grown for $2 \mathrm{~h}$ in $5 \mathrm{~mL}$ of brain-heart infusion (BHI) broth (Becton Dickinson, Allschwil, Switzerland) at $37^{\circ} \mathrm{C}$ in a shaking incubator to reach mid-log bacterial phase. For each host bacteria, $100 \mu \mathrm{L}$ of a $0.5 \mathrm{McF}$ arland bacterial suspension was mixed in a BHI agarose matrix ('top agar', $0.6 \%$ ), which was then distributed to solidify on a standard BHI agar plate ('bottom agar', 1.5\%, dried for $2 \mathrm{~h}$ before use at room temperature). After drying, $10 \mu \mathrm{L}$ of each of the four phage suspensions was spotted on the plate and was incubated overnight.

The next day, lysis zones (if any) were quantified using a common system assessing the success of phage infection [20]. In particular, strains showing confluent lysis (i.e. complete clearing: '++++'), semiconfluent lysis (i.e. clearing throughout but with faintly hazy background: ' +++ '), opaque lysis (i.e. turbidity 
throughout the cleared zone: ' ++ ') or 'tâches vièrges' (i.e. individual clear or opaque plaques: ' + ') were defined as susceptible to the phage compounds tested. Strains showing no activity (i.e. no clearing: ' $R$ ') were defined as resistant.

All of the susceptibility tests were performed at the Institute for Infectious Diseases of the University of Bern between 29 August 2016 and 6 October 2016 by two of the authors (OJB and RT). The spot test was performed two times on different days, using vials belonging to different boxes (except for PYO, for which two vials of the same box were tested) and BHI broth/agar plates prepared in different sessions. Results were interpreted by at least three operators and showed consistency for all tested strains, with no difference greater than one ' $t$ ' between the two experiments (with very few exceptions, for which a third assay was performed).

\section{Results and discussion}

\subsection{Escherichia coli strains}

As shown in Table 3, the overall susceptibility of E. coli strains to PYO, INTESTI and Septaphage was $61.4 \%$ (including $7 / 70$ with ' +++ ' and $6 / 70$ with ' ++++ '), $67.1 \%$ (including $9 / 70$ with ' +++ ' and 5/70 with ' ++++ ') and $8.6 \%$ (including 4/70 with ' ++++ '), respectively. In particular, PYO cocktail showed lytic activity against $67.7 \%(21 / 31), 50.0 \%(11 / 12)$ and $66.7 \%(8 / 12)$ of human, animal and food strains, whereas the activities for INTESTI were 64.5\% (20/31), 63.6\% (14/22) and 75.0\% (9/12), respectively (Table 1).

For the overall subgroup of the ESBL-producing E. coli strains ( $n=37)$, the following susceptible rates were recorded: PYO, 54.0\%; INTESTI, 56.7\%; and Septaphage, 2.7\% (Table 3). In the study by FitzgeraldHughes et al., 100 phenotypically defined ESBL-producing E. coli were susceptible to PYO and INTESTI in $36 \%$ and $54 \%$ of cases, respectively [11]. Septaphage was not tested, but the authors indicated that two additional phage cocktails, not tested in the present study, were much more active (i.e. SES and ENKO, at $87 \%$ and $89 \%$, respectively) [11]. In another analysis testing only nine ESBL-producing E. coli strains, Sybesma et al. obtained the following susceptibility rates: PYO, 78\%; and INTESTI, SES and ENKO, all 89\% [12].

With regard to the pAmpC-producing E. coli strains ( $n=21), 71.4 \%$ and $85.7 \%$ were susceptible to PYO and INTESTI, respectively, whereas only $14.3 \%$ were susceptible to Septaphage. Moreover, five of seven carbapenemase-producers and three of four colistin-resistant strains (including the MCR-1-producer) were susceptible to PYO and INTESTI, respectively (Tables 1 and 3). We highlight that no previous 
studies have analysed the lytic activity of commercial bacteriophage cocktails against this specific group of MDR E. coli strains. Data regarding the life-threatening carbapenem- and colistin-resistant strains were promising $[4,5,21]$ but should be confirmed testing a larger collection of strains.

In this study, five of seven E. coli strains belonging to the hyperepidemic clones ST131 and ST648 [22] were susceptible both to PYO and INTESTI (Tables 1 and 3). We also emphasise that the activity of the phage compounds was relatively different even though the E. coli strains belonged to the same STs (e.g. see the results of the five ST131 and four ST420 strains in Table 1). These differences probably depend on the fact that some bacterial clones may acquire and develop different escape strategies (e.g. inhibition of CRISPR-Cas or phage adsorption systems) against bacteriophages [23]. Therefore, as recently explored for $S$. Typhimurium [24], further studies with a larger collection of hyperepidemic $E$. coli clones coupled with whole-genome sequence analyses should be performed to clarify the underlying molecular mechanisms that make each unique bacteria resistant to phage attack.

\subsection{Proteus spp. strains}

As anticipated, published data regarding the activity of commercial bacteriophage cocktails against Proteus spp. strains are lacking. In the present study, the overall susceptibility of Proteus spp. to PYO, INTESTI and Septaphage was $29.0 \%$ (including 3/31 with ' +++ ' or ' ++++ '), $38.7 \%$ (including 4/31 with ' +++ ' or ' ++++ ') and $19.3 \%$ (including 5/31 with ' +++ ' or ' ++++ '), respectively (Table 2 and 3). In particular, the following susceptibility rates were recorded for $P$. mirabilis and $P$. vulgaris, respectively: PYO, 33.3\% and $20.0 \%$; INTESTI, $47.6 \%$ and $20.0 \%$, and Septaphage, $28.6 \%$ and $0 \%$. With regard to the MDR P. mirabilis strains ( $n=15$ ), $40.0 \%$ were susceptible both to PYO and INTESTI, whereas only $26.7 \%$ were susceptible to Septaphage (Table 3 ). Owing to the relatively small number of tested strains, larger collections of MDR Proteus spp. should be tested to confirm these results.

\subsection{Overall strains}

Surprisingly, Septaphage displayed an almost complete lack of activity both against E. coli and Proteus spp. strains. Moreover, a noteworthy variability between the two preparations expected to target the same bacterial species (i.e. INTESTI and Septaphage) could be noted (Table 3). This may be linked to the different content in terms of strains-specific bacteriophages with lytic activity. However, to our knowledge, only the INTESTI preparation has been well characterised using metagenomic analyses [25]. Alternatively, the reason for such remarkable divergences among the phage compounds could rely on different production methods [26], leading to insufficient viral titre of the final biopreparation. In this context, we note that a concentration of $10^{5-6} \mathrm{PFU} / \mathrm{mL}$ is indicated both for INTESTI and PYO, whereas the concentration is $10^{5} \mathrm{PFU} / \mathrm{mL}$ for Septaphage. 
The overall narrow spectrum of activity of the cocktails observed against the MDR E. coli and Proteus spp. analysed in this study could be related to the absence of specific bacteriophages targeting these contemporary strains that are usually responsible for human infections both in hospital and community settings $[17,22,27-29]$. Besides, it is remarkable that most of the fully antibiotic-sensitive $P$. mirabilis and $P$. vulgaris strains $(10 / 16 ; 62.5 \%)$ were shown to be completely resistant to the bacteriophage cocktails with declared activity against such species.

Therefore, the spectrum of activity of the above cocktails should be expanded integrating new lytic phages. We note for instance that Dufour et al. have recently selected a bacteriophage (LM33_P1) with lytic activity against ca. $65 \%$ of ST131 E. coli isolates tested and also able to significantly reduce the organ bacterial load in pneumonia, septicaemia and UTI in in vivo models [9]. Pouillot et al. isolated another bacteriophage $\left(\mathrm{EC} 200^{\mathrm{PP}}\right)$ specific for $E$. coli ST131: although no data regarding its spectrum of activity against a collection of ST131 strains was provided, this phage demonstrated potent activity in sepsis and meningitis in vivo models [10].

A limited number of bacteriophages infecting Proteus spp. have so far been selected and studied $[30,31]$. Nevertheless, we underline that Melo et al. have recently isolated and characterised a novel bacteriophage (Pm5461) that was able to target all 26 Proteus spp. tested in the study. Unfortunately, the antimicrobial susceptibility phenotype of the strains and their year of collection were not defined [32].

Finally, we should note that the spot test can lead to an overestimation of positive results as a consequence of the 'lysis-from-without' phenomenon [33]. We are therefore aware that the results of the current study might partially overestimate the susceptibility results for PYO and INTESTI compounds.

\section{Conclusions}

Escherichia coli and Proteus spp. are frequently responsible for UTIs and bacteraemia [27,34]. Furthermore, difficult-to-treat infections due to MDR E. coli and Proteus spp. are increasing worldwide, leading to higher morbidity and mortality rates $[1,28,29,35]$. We also note that such MDR pathogens can cause intestinal colonisation of humans $[5,16]$ and animals $[2,14,18,21]$, along with contamination of the food chain $[3,36,37]$. Since exchange of MDR strains among these settings has been demonstrated $[2,18]$, this overall phenomenon, also known as the 'One-Health concept', contributes enormously to the expansion and spread of MDR Enterobacteriaceae [38]. 
In this scenario, we therefore explored the use of bacteriophages as a possible alternative to antibiotics. In particular, we assessed for the first time the in vitro susceptibility of a large collection of wellcharacterised E. coli and Proteus spp. to three commercial bacteriophage cocktails. This information is essential to understand whether these phage compounds can be hypothetically implemented in large scale to treat infections (e.g. UTIs) [6,7], to decolonise intestinal carriers and/or to decontaminate food stuffs [39] from current MDR E. coli and Proteus spp.

As a result of the analysis, we observed neither strong lysis ('+++' to ' ++++ ') for the majority of the tested strains, nor a wide spectrum of activity against the total number of bacteria, especially regarding Proteus spp. The most active compound (INTESTI) showed ca. $70 \%$ and $40 \%$ activity against $E$. coli and Proteus spp., respectively (although only $15-20 \%$ with activity $\geq$ ' +++ ').

The great diversity of currently circulating MDR E. coli and Proteus spp. is partially exemplified by the bacterial collection studied here. The tested cocktails contained only a few bacterial viruses targeting such contemporary pathogens. Therefore, new bacteriophages active against emerging MDR strains need to be isolated and integrated in such biopreparations. Only in this way will phage libraries start to reflect the worldwide and actual situation of MDR and pandemic isolates [22]. Moreover, the newly isolated bacteriophages should also be well characterised $[9,10,25,32]$ and should be produced according to Good Manufacturing Practice (GMP) standards in order to become, at a later stage, approved for clinical therapy $[7,26]$.

To become a real alternative to standard antimicrobials, phage cocktails first need to be brought up to date in terms of clinically relevant strain-specific viral content [40]. Only then will the progress towards therapeutic use of bacteriophages for the management of difficult-to-treat infections caused by MDR organisms meet a ground to grow and flourish also in the Western world.

Acknowledgments: The authors thank Drs Alessandra Carattoli, Catherine Neuwirth, Vincent Perreten, Francesco Luzzaro and Robert A. Bonomo for providing several MDR E. coli strains. The authors are also grateful to Dr Cédric Hirzel for acquiring the commercial phage cocktails during a trip to Georgia. The authors also thank Dr Natia Karumidze for her precious suggestions during her stay (11 September 2015 to 19 August 2016) at the Institute for Infectious Diseases of the University of Bern (Bern, Switzerland) as a Postdoctoral Student, supported by a Swiss Government Excellence Scholarship. 
Funding: This work was supported by the Swiss National Science Foundation [grant no. 153377 to AE]. OJB is a PhD student (2015-2018) supported by the Hans Sigrist Foundation (University of Bern, Bern, Switzerland).

Competing interests: None declared.

Ethical approval: Not required. 


\section{References}

[1] Seiffert SN, Hilty M, Kronenberg A, Droz S, Perreten V, Endimiani A. Extended-spectrum cephalosporin-resistant Escherichia coli in community, specialized outpatient clinic and hospital settings in Switzerland. J Antimicrob Chemother 2013;68:2249-54.

[2] Seiffert SN, Hilty M, Perreten V, Endimiani A. Extended-spectrum cephalosporin-resistant Gramnegative organisms in livestock: an emerging problem for human health? Drug Resist Updat 2013;16:22-45.

[3] Seiffert SN, Tinguely R, Lupo A, Neuwirth C, Perreten V, Endimiani A. High prevalence of extended-spectrum-cephalosporin-resistant Enterobacteriaceae in poultry meat in Switzerland: emergence of CMY-2- and VEB-6-possessing Proteus mirabilis. Antimicrob Agents Chemother 2013;57:6406-8.

[4] Lee CR, Lee JH, Park KS, Kim YB, Jeong BC, Lee SH. Global dissemination of carbapenemaseproducing Klebsiella pneumoniae: epidemiology, genetic context, treatment options, and detection methods. Front Microbiol 2016;7:895.

[5] Bernasconi OJ, Kuenzli E, Pires J, Tinguely R, Carattoli A, Hatz C, et al. Travelers can import colistin-resistant Enterobacteriaceae, including those possessing the plasmid-mediated $\mathrm{mcr}$-1 gene. Antimicrob Agents Chemother 2016;60:5080-4.

[6] Domingo-Calap P, Georgel P, Bahram S. Back to the future: bacteriophages as promising therapeutic tools. HLA 2016;87:133-40.

[7] Vandenheuvel D, Lavigne R, Brussow H. Bacteriophage therapy: advances in formulation strategies and human clinical trials. Annu Rev Virol 2015;2:599-618.

[8] Wang J, Hu B, Xu M, Yan Q, Liu S, Zhu X, et al. Therapeutic effectiveness of bacteriophages in the rescue of mice with extended spectrum $\beta$-lactamase-producing Escherichia coli bacteremia. Int J Mol Med 2006;17:347-55.

[9] Dufour N, Clermont O, La Combe B, Messika J, Dion S, Khanna V, et al. Bacteriophage LM33_P1, a fast-acting weapon against the pandemic ST131-O25b:H4 Escherichia coli clonal complex. J Antimicrob Chemother 2016;71:3072-80.

[10]Pouillot F, Chomton M, Blois H, Courroux C, Noelig J, Bidet P, et al. Efficacy of bacteriophage therapy in experimental sepsis and meningitis caused by a clone O25b:H4-ST131 Escherichia coli strain producing CTX-M-15. Antimicrob Agents Chemother 2012;56:3568-75.

[11]Fitzgerald-Hughes D, Bolkvadze D, Balarjishvili N, Leshkasheli L, Ryan M, Burke L, et al. Susceptibility of extended-spectrum- $\beta$-lactamase-producing Escherichia coli to commercially available and laboratory-isolated bacteriophages. J Antimicrob Chemother 2014;69:1148-50. 
[12]Sybesma W, Zbinden R, Chanishvili N, Kutateladze M, Chkhotua A, Ujmajuridze A, et al. Bacteriophages as potential treatment for urinary tract infections. Front Microbiol 2016;7:465.

[13] Gundogdu A, Bolkvadze D, Kilic $H$. In vitro effectiveness of commercial bacteriophage cocktails on diverse extended-spectrum $\beta$-lactamase producing Escherichia coli strains. Front Microbiol 2016;7:1761.

[14]Endimiani A, Rossano A, Kunz D, Overesch G, Perreten V. First countrywide survey of thirdgeneration cephalosporin-resistant Escherichia coli from broilers, swine, and cattle in Switzerland. Diagn Microbiol Infect Dis 2012;73:31-8.

[15]Pires J, Tinguely R, Thomas B, Luzzaro F, Endimiani A. Comparison of the in-house made CarbaNP and Blue-Carba tests: considerations for better detection of carbapenemase-producing Enterobacteriaceae. J Microbiol Methods 2016;122:33-7.

[16]Pires J, Kuenzli E, Kasraian S, Tinguely R, Furrer H, Hilty M, et al. Polyclonal intestinal colonization with extended-spectrum cephalosporin-resistant Enterobacteriaceae upon traveling to India. Front Microbiol 2016;7:1069.

[17]Seiffert SN, Perreten V, Johannes S, Droz S, Bodmer T, Endimiani A. OXA-48 carbapenemaseproducing Salmonella enterica serovar Kentucky isolate of sequence type 198 in a patient transferred from Libya to Switzerland. Antimicrob Agents Chemother 2014;58:2446-9.

[18]Pires J, Bernasconi OJ, Kasraian S, Hilty M, Perreten V, Endimiani A. Intestinal colonisation with extended-spectrum cephalosporin-resistant Escherichia coli in Swiss pets: molecular features, risk factors and transmission with owners. Int J Antimicrob Agents 2016;48:759-60.

[19] Magiorakos AP, Srinivasan A, Carey RB, Carmeli Y, Falagas ME, Giske CG, et al. Multidrugresistant, extensively drug-resistant and pandrug-resistant bacteria: an international expert proposal for interim standard definitions for acquired resistance. Clin Microbiol Infect 2012;18:268-81.

[20]Clokie MRJ, Kropinski A, editors. Bacteriophages. Methods and protocols, Volume 1: Isolation, characterization, and interactions. Humana Press; 2009.

[21]Schwarz S, Johnson AP. Transferable resistance to colistin: a new but old threat. J Antimicrob Chemother 2016;71:2066-70.

[22]Woodford N, Turton JF, Livermore DM. Multiresistant Gram-negative bacteria: the role of highrisk clones in the dissemination of antibiotic resistance. FEMS Microbiol Rev 2011;35:736-55.

[23]Samson JE, Magadan AH, Sabri M, Moineau S. Revenge of the phages: defeating bacterial defences. Nat Rev Microbiol 2013;11:675-87. 
[24]Mohammed $M$, Cormican $M$. Whole genome sequencing provides possible explanations for the difference in phage susceptibility among two Salmonella Typhimurium phage types (DT8 and DT30) associated with a single foodborne outbreak. BMC Res Notes 2015;8:728.

[25]Zschach H, Joensen KG, Lindhard B, Lund O, Goderdzishvili M, Chkonia I, et al. What can we learn from a metagenomic analysis of a Georgian bacteriophage cocktail? Viruses 2015;7:657089.

[26]Pirnay JP, Blasdel BG, Bretaudeau L, Buckling A, Chanishvili N, Clark JR, et al. Quality and safety requirements for sustainable phage therapy products. Pharm Res 2015;32:2173-9.

[27]Schaffer JN, Pearson MM. Proteus mirabilis and urinary tract infections. Microbiol Spectr 2015;3, doi: 10.1128/microbiolspec.UTI-0017-2013.

[28]Endimiani A, Luzzaro F, Brigante G, Perilli M, Lombardi G, Amicosante G, et al. Proteus mirabilis bloodstream infections: risk factors and treatment outcome related to the expression of extended-spectrum $\beta$-lactamases. Antimicrob Agents Chemother 2005;49:2598-605.

[29]Kronenberg A, Hilty M, Endimiani A, Muhlemann K. Temporal trends of extended-spectrum cephalosporin-resistant Escherichia coli and Klebsiella pneumoniae isolates in in- and outpatients in Switzerland, 2004 to 2011. Euro Surveill 2013;18:pii: 20484 .

[30]Morozova V, Kozlova Y, Shedko E, Kurilshikov A, Babkin I, Tupikin A, et al. Lytic bacteriophage PM16 specific for Proteus mirabilis: a novel member of the genus Phikmvvirus. Arch Virol 2016;161:2457-72.

[31] Maszewska A, Wojcik E, Ciurzynska A, Wojtasik A, Piatkowska I, Dastych J, et al. Differentiation of polyvalent bacteriophages specific to uropathogenic Proteus mirabilis strains based on the host range pattern and RFLP. Acta Biochim Pol 2016;63:303-10.

[32] Melo LD, Veiga P, Cerca N, Kropinski AM, Almeida C, Azeredo J, et al. Development of a phage cocktail to control Proteus mirabilis catheter-associated urinary tract infections. Front Microbiol 2016;7:1024.

[33] Khan Mirzaei M, Nilsson AS. Isolation of phages for phage therapy: a comparison of spot tests and efficiency of plating analyses for determination of host range and efficacy. PLoS One 2015;10:e0118557.

[34]Buetti N, Marschall J, Atkinson A, Kronenberg A. National bloodstream infection surveillance in Switzerland 2008-2014: different patterns and trends for university and community hospitals. Infect Control Hosp Epidemiol 2016;37:1060-7.

[35] Marchaim D, Gottesman T, Schwartz O, Korem M, Maor Y, Rahav G, et al. National multicenter study of predictors and outcomes of bacteremia upon hospital admission caused by 
Enterobacteriaceae producing extended-spectrum $\beta$-lactamases. Antimicrob Agents Chemother 2010;54:5099-104.

[36]Vogt D, Overesch G, Endimiani A, Collaud A, Thomann A, Perreten V. Occurrence and genetic characteristics of third-generation cephalosporin-resistant Escherichia coli in Swiss retail meat. Microb Drug Resist 2014;20:485-94.

[37]Zurfluh K, Nuesch-Inderbinen M, Morach M, Zihler Berner A, Hachler H, Stephan R. Extendedspectrum $\beta$-lactamase-producing Enterobacteriaceae isolated from vegetables imported from the Dominican Republic, India, Thailand, and Vietnam. Appl Environ Microbiol 2015;81:3115-20.

[38] Collignon P. The importance of a One Health approach to preventing the development and spread of antibiotic resistance. Curr Top Microbiol Immunol 2013;366:19-36.

[39]Sulakvelidze A. Using lytic bacteriophages to eliminate or significantly reduce contamination of food by foodborne bacterial pathogens. J Sci Food Agric 2013;93:3137-46.

[40]Mattila S, Ruotsalainen P, Jalasvuori M. On-demand isolation of bacteriophages against drugresistant bacteria for personalized phage therapy. Front Microbiol 2015;6:1271. 


\section{Table 1}

Characteristics of 70 multidrug-resistant Escherichia coli strains and their susceptibility to four commercial bacteriophage cocktails

\begin{tabular}{|c|c|c|c|c|c|c|c|c|c|c|c|}
\hline \multirow[t]{2}{*}{ Strain ID } & \multirow{2}{*}{$\begin{array}{l}\text { Origin } \\
\text { (source; } \\
\text { year of } \\
\text { isolation } \\
\text { ) }\end{array}$} & \multirow{2}{*}{$\begin{array}{l}\text { Main } \\
\text { bla } \\
\text { gene } \\
\text { s }\end{array}$} & \multirow[t]{2}{*}{$S T^{a}$} & \multicolumn{5}{|c|}{$\begin{array}{l}\text { Susceptibility according } \\
\text { to EUCAST }{ }^{\text {b }}\end{array}$} & \multicolumn{3}{|c|}{$\begin{array}{l}\text { Bacteriophage } \\
\text { susceptibility }{ }^{c}\end{array}$} \\
\hline & & & & $\begin{array}{l}\text { CT } \\
x\end{array}$ & $\begin{array}{l}\mathrm{IP} \\
\mathrm{M}\end{array}$ & $\begin{array}{l}\mathrm{Cl} \\
\mathrm{P}\end{array}$ & $\begin{array}{l}\text { GE } \\
N\end{array}$ & $\begin{array}{l}\mathrm{C} \\
\mathrm{OL}\end{array}$ & $\begin{array}{l}\text { PY } \\
\mathrm{O}\end{array}$ & $\begin{array}{l}\text { INTE } \\
\text { STI }\end{array}$ & $\begin{array}{l}\text { Septaph } \\
\text { age }\end{array}$ \\
\hline 4811.56 & $\begin{array}{l}\text { Human } \\
\text { (vagina } \\
\text { ।; } \\
\text { 2011) }\end{array}$ & $\begin{array}{c}\text { CTX- } \\
\text { M- } \\
15\end{array}$ & $\begin{array}{r}\text { ST1 } \\
31\end{array}$ & $\mathrm{R}$ & $S$ & $S$ & $S$ & $S$ & $\mathrm{R}$ & $\mathrm{R}$ & $\mathrm{R}$ \\
\hline 4901.28 & $\begin{array}{l}\text { Human } \\
\text { (urine; } \\
\text { 2011) }\end{array}$ & $\begin{array}{c}\text { CTX- } \\
\text { M- } \\
15\end{array}$ & $\begin{array}{r}\text { ST1 } \\
31\end{array}$ & $\mathrm{R}$ & $S$ & $\mathrm{R}$ & $\mathrm{R}$ & $S$ & $\begin{array}{r}++ \\
+\end{array}$ & +++ & $\mathrm{R}$ \\
\hline $\begin{array}{l}\text { LA1209503 } \\
\text { 8/Ec-38 }\end{array}$ & $\begin{array}{l}\text { Human } \\
\text { (urine; } \\
\text { 2012) }\end{array}$ & $\begin{array}{c}\text { CTX- } \\
\text { M- } \\
15\end{array}$ & $\begin{array}{r}\text { ST1 } \\
31\end{array}$ & $\mathrm{R}$ & $S$ & $\mathrm{R}$ & $\mathrm{R}$ & $S$ & $\begin{array}{r}++ \\
++\end{array}$ & +++ & $\mathrm{R}$ \\
\hline 4809.08 & $\begin{array}{l}\text { Human } \\
\text { (liver } \\
\text { absces } \\
\text { s; } \\
\text { 2011) }\end{array}$ & $\begin{array}{c}\text { CTX- } \\
\text { M- } \\
15\end{array}$ & $\begin{array}{r}\text { ST6 } \\
48\end{array}$ & $\mathrm{R}$ & $S$ & $\mathrm{R}$ & $\mathrm{R}$ & $S$ & $\mathrm{R}$ & $\mathrm{R}$ & $\mathrm{R}$ \\
\hline 8-R MAC III & $\begin{array}{r}\text { Human } \\
\text { (stool; } \\
2015 \text { ) }\end{array}$ & $\begin{array}{c}\text { CTX- } \\
\text { M- } \\
15\end{array}$ & $\begin{array}{r}\text { ST6 } \\
48\end{array}$ & $\mathrm{R}$ & $S$ & $\mathrm{R}$ & $\mathrm{R}$ & $S$ & ++ & ++ & $\mathrm{R}$ \\
\hline
\end{tabular}




\begin{tabular}{|c|c|c|c|c|c|c|c|c|c|c|c|}
\hline MSA971 & $\begin{array}{l}\text { Poultry } \\
\text { (cloaca } \\
\text { ।; } \\
2010- \\
2011 \text { ) }\end{array}$ & $\begin{array}{l}\text { CTX- } \\
\text { M- } \\
15\end{array}$ & $\begin{array}{r}\text { ST5 } \\
33\end{array}$ & $\mathrm{R}$ & $S$ & I & $\mathrm{R}$ & $S$ & $\mathrm{R}$ & + & $\mathrm{R}$ \\
\hline $\begin{array}{l}\text { 83-R MAC } \\
\text { III }\end{array}$ & $\begin{array}{l}\text { Human } \\
\text { (stool; } \\
\text { 2015) }\end{array}$ & $\begin{array}{l}\text { CTX- } \\
\text { M- } \\
15\end{array}$ & $\begin{array}{r}\text { ST3 } \\
94\end{array}$ & $\mathrm{R}$ & $S$ & $S$ & $S$ & $S$ & $\mathrm{R}$ & $\mathrm{R}$ & $\mathrm{R}$ \\
\hline 97R Drigl & $\begin{array}{l}\text { Human } \\
\text { (stool; } \\
\text { 2015) }\end{array}$ & $\begin{array}{l}\text { CTX- } \\
\text { M- } \\
15\end{array}$ & $\begin{array}{c}\text { ST2 } \\
91\end{array}$ & $\mathrm{R}$ & S & $S$ & $S$ & $S$ & + & $\mathrm{R}$ & $\mathrm{R}$ \\
\hline 23-R Drigll & $\begin{array}{l}\text { Human } \\
\text { (stool; } \\
\text { 2015) }\end{array}$ & $\begin{array}{l}\text { CTX- } \\
\text { M- } \\
15\end{array}$ & $\begin{array}{c}\text { ST2 } \\
00\end{array}$ & $S$ & $S$ & $S$ & $S$ & $S$ & + & + & $\mathrm{R}$ \\
\hline 8-R MAC I & $\begin{array}{l}\text { Human } \\
\text { (stool; } \\
\text { 2015) }\end{array}$ & $\begin{array}{l}\text { CTX- } \\
\text { M- } \\
15\end{array}$ & $\begin{array}{r}\text { ST2 } \\
45\end{array}$ & $\mathrm{R}$ & $S$ & $\mathrm{R}$ & $\mathrm{R}$ & $S$ & + & + & $\mathrm{R}$ \\
\hline $\begin{array}{l}\text { 73-R } \\
\text { chromB }\end{array}$ & $\begin{array}{l}\text { Human } \\
\text { (stool; } \\
\text { 2015) }\end{array}$ & $\begin{array}{l}\text { CTX- } \\
\text { M- } \\
15\end{array}$ & $\begin{array}{c}\text { ST4 } \\
12\end{array}$ & $\mathrm{R}$ & $S$ & $S$ & $S$ & $S$ & ++ & + & $\mathrm{R}$ \\
\hline $\begin{array}{l}\text { IMD0077/1 } \\
1\end{array}$ & $\begin{array}{l}\text { Cattle } \\
\text { (stool; } \\
\text { 2010- } \\
\text { 2011) }\end{array}$ & $\begin{array}{l}\text { CTX- } \\
\text { M- } \\
15\end{array}$ & $\begin{array}{r}S T 5 \\
37\end{array}$ & $\mathrm{R}$ & $S$ & $\mathrm{R}$ & $S$ & $S$ & $\mathrm{R}$ & $\mathrm{R}$ & $\mathrm{R}$ \\
\hline Sidava & $\begin{array}{l}\text { Cat } \\
\text { (stool; } \\
\text { 2015) }\end{array}$ & $\begin{array}{l}\text { CTX- } \\
\text { M- } \\
15\end{array}$ & $\begin{array}{c}\text { ST7 } \\
3\end{array}$ & $\mathrm{R}$ & $S$ & $S$ & $S$ & $S$ & $\mathrm{R}$ & + & $\mathrm{R}$ \\
\hline
\end{tabular}




\begin{tabular}{|c|c|c|c|c|c|c|c|c|c|c|c|}
\hline 68-M3 Supl & $\begin{array}{c}\text { Human } \\
\text { (stool; } \\
\text { 2015) }\end{array}$ & $\begin{array}{l}\text { CTX- } \\
\text { M- } \\
\text { 15- } \\
\text { like }\end{array}$ & $\begin{array}{c}\text { ST4 } \\
8\end{array}$ & $\mathrm{R}$ & $S$ & $S$ & $\mathrm{~S}$ & $\mathrm{~S}$ & $\mathrm{R}$ & $\mathrm{R}$ & $\mathrm{R}$ \\
\hline 97-R Drigll & $\begin{array}{c}\text { Human } \\
\text { (stool; } \\
\text { 2015) }\end{array}$ & $\begin{array}{l}\text { CTX- } \\
\text { M- } \\
\text { 15- } \\
\text { like }\end{array}$ & $\begin{array}{c}\text { ST8 } \\
41\end{array}$ & $\mathrm{R}$ & $S$ & $S$ & $S$ & $S$ & $\mathrm{R}$ & + & $\mathrm{R}$ \\
\hline 29-R Maclll & $\begin{array}{c}\text { Human } \\
\text { (stool; } \\
\text { 2015) }\end{array}$ & $\begin{array}{l}\text { CTX- } \\
\text { M- } \\
\text { 15- } \\
\text { like }\end{array}$ & $\begin{array}{c}\text { ST3 } \\
49\end{array}$ & $\mathrm{R}$ & $S$ & $S$ & $S$ & $S$ & + & $\mathrm{R}$ & $\mathrm{R}$ \\
\hline 43-R Drig & $\begin{array}{c}\text { Human } \\
\text { (stool; } \\
\text { 2015) }\end{array}$ & $\begin{array}{l}\text { CTX- } \\
\text { M- } \\
\text { 15- } \\
\text { like }\end{array}$ & $\begin{array}{c}\text { ST6 } \\
17\end{array}$ & $\mathrm{R}$ & $S$ & $\mathrm{R}$ & $S$ & $S$ & $\mathrm{R}$ & $\mathrm{R}$ & $\mathrm{R}$ \\
\hline $\begin{array}{c}\text { 56-M3-Ec- } \\
\text { Col-R }\end{array}$ & $\begin{array}{c}\text { Human } \\
\text { (stool; } \\
\text { 2015) }\end{array}$ & $\begin{array}{l}\text { CTX- } \\
\text { M- } \\
\text { 15- } \\
\text { like }\end{array}$ & $\begin{array}{c}\text { ST6 } \\
30\end{array}$ & $\mathrm{R}$ & $S$ & $\mathrm{R}$ & $S$ & $\mathrm{R}$ & $\begin{array}{c}++ \\
++\end{array}$ & ++++ & $\mathrm{R}$ \\
\hline Ylraz I & $\begin{array}{l}\text { Dog } \\
\text { (stool; } \\
\text { 2013) }\end{array}$ & $\begin{array}{l}\text { CTX- } \\
\text { M-1 }\end{array}$ & $\begin{array}{c}\text { ST9 } \\
49\end{array}$ & $\mathrm{R}$ & $S$ & $S$ & $S$ & $S$ & $\mathrm{R}$ & $\mathrm{R}$ & $\mathrm{R}$ \\
\hline $\begin{array}{l}\text { IMD0041/1 } \\
1\end{array}$ & $\begin{array}{l}\text { Swine } \\
\text { (stool; } \\
\text { 2010- } \\
\text { 2011) }\end{array}$ & $\begin{array}{l}\text { CTX- } \\
M-1\end{array}$ & $\begin{array}{r}\text { ST5 } \\
29\end{array}$ & $\mathrm{R}$ & $S$ & I & $S$ & $S$ & ++ & + & $\mathrm{R}$ \\
\hline $5 \mathrm{~A}$ & $\begin{array}{c}\text { Chicken } \\
\text { meat } \\
(2012)\end{array}$ & $\begin{array}{l}\text { CTX- } \\
\text { M-1 }\end{array}$ & $\begin{array}{c}\text { ST2 } \\
48\end{array}$ & $\mathrm{R}$ & $S$ & $S$ & $S$ & $S$ & $\mathrm{R}$ & $\mathrm{R}$ & $\mathrm{R}$ \\
\hline
\end{tabular}




\begin{tabular}{|c|c|c|c|c|c|c|c|c|c|c|c|}
\hline $7 \mathrm{~A}$ & $\begin{array}{c}\text { Chicken } \\
\text { meat } \\
(2012)\end{array}$ & $\begin{array}{l}\text { CTX- } \\
M-1\end{array}$ & $\begin{array}{c}\text { ST1 } \\
14\end{array}$ & $\mathrm{R}$ & $\mathrm{S}$ & $S$ & $S$ & $S$ & + & + & $\mathrm{R}$ \\
\hline $7 \mathrm{~B}$ & $\begin{array}{c}\text { Chicken } \\
\text { meat } \\
(2012)\end{array}$ & $\begin{array}{l}\text { CTX- } \\
\text { M-1 }\end{array}$ & na & $\mathrm{R}$ & $S$ & $S$ & $S$ & $S$ & $\begin{array}{r}++ \\
+\end{array}$ & ++++ & 0 \\
\hline $11 \mathrm{~A}$ & $\begin{array}{c}\text { Chicken } \\
\text { meat } \\
(2012)\end{array}$ & $\begin{array}{l}\text { CTX- } \\
M-1\end{array}$ & $\begin{array}{c}\text { ST1 } \\
30\end{array}$ & $\mathrm{R}$ & $S$ & $S$ & $S$ & $S$ & + & + & $\mathrm{R}$ \\
\hline $9 A$ & $\begin{array}{c}\text { Chicken } \\
\text { meat } \\
(2012)\end{array}$ & $\begin{array}{l}\text { CTX- } \\
M-1\end{array}$ & $\begin{array}{c}\text { ST6 } \\
02\end{array}$ & $\mathrm{R}$ & $S$ & $S$ & $S$ & $S$ & + & + & $\mathrm{R}$ \\
\hline $18 \mathrm{~A}$ & $\begin{array}{c}\text { Chicken } \\
\text { meat } \\
(2012)\end{array}$ & $\begin{array}{l}\text { CTX- } \\
M-1\end{array}$ & $\begin{array}{l}\text { ST2 } \\
3\end{array}$ & $\mathrm{R}$ & $S$ & $S$ & $S$ & $S$ & + & +++ & $\mathrm{R}$ \\
\hline $20 \mathrm{C}$ & $\begin{array}{c}\text { Chicken } \\
\text { meat } \\
(2012)\end{array}$ & $\begin{array}{l}\text { CTX- } \\
M-1\end{array}$ & na & $\mathrm{R}$ & $S$ & S & $S$ & $S$ & ++ & + & $\mathrm{R}$ \\
\hline $\begin{array}{l}\text { 100-R- } \\
\text { Chromll }\end{array}$ & $\begin{array}{l}\text { Human } \\
\text { (stool; } \\
\text { 2015) }\end{array}$ & $\begin{array}{l}\text { CTX- } \\
\text { M } \\
\text { grou } \\
\text { p } 1\end{array}$ & na & $\mathrm{R}$ & $S$ & $S$ & $S$ & $S$ & $\mathrm{R}$ & $\mathrm{R}$ & $\mathrm{R}$ \\
\hline 100-R-Drig & $\begin{array}{l}\text { Human } \\
\text { (stool; } \\
\text { 2015) }\end{array}$ & $\begin{array}{l}\text { CTX- } \\
\text { M } \\
\text { grou } \\
\text { p } 1\end{array}$ & $\begin{array}{c}\text { ST1 } \\
55\end{array}$ & $\mathrm{R}$ & $S$ & $S$ & $S$ & $S$ & + & + & ++++ \\
\hline Socra & $\begin{array}{l}\text { Dog } \\
\text { (stool; } \\
\text { 2015) }\end{array}$ & $\begin{array}{l}\text { CTX- } \\
\text { M- } \\
14\end{array}$ & $\begin{array}{c}\text { ST1 } \\
62\end{array}$ & $\mathrm{R}$ & $S$ & $S$ & $\mathrm{R}$ & $S$ & $\mathrm{R}$ & $\mathrm{R}$ & $\mathrm{R}$ \\
\hline
\end{tabular}




\begin{tabular}{|c|c|c|c|c|c|c|c|c|c|c|c|}
\hline $\begin{array}{l}\text { 11/IMD047 } \\
7\end{array}$ & $\begin{array}{l}\text { Poultry } \\
\text { (cloaca } \\
\text { I; } \\
2010- \\
2011 \text { ) }\end{array}$ & $\begin{array}{l}\text { TEM- } \\
52\end{array}$ & $\begin{array}{r}\text { ST5 } \\
24\end{array}$ & $I$ & $S$ & I & $S$ & $S$ & + & + & $\mathrm{R}$ \\
\hline $\begin{array}{l}\text { IMD } \\
\text { 0050/11 }\end{array}$ & $\begin{array}{l}\text { Poultry } \\
\text { (cloaca } \\
\text { I; } \\
2010- \\
11 \text { ) }\end{array}$ & $\begin{array}{l}\text { TEM- } \\
52\end{array}$ & $\begin{array}{c}\text { ST8 } \\
6\end{array}$ & $\mathrm{R}$ & $S$ & $S$ & $S$ & $S$ & $\mathrm{R}$ & $\mathrm{R}$ & $\mathrm{R}$ \\
\hline $4 \mathrm{~A}$ & $\begin{array}{c}\text { Chicken } \\
\text { meat } \\
(2012)\end{array}$ & $\begin{array}{l}\text { TEM- } \\
52\end{array}$ & $\begin{array}{c}\text { ST2 } \\
3\end{array}$ & $\mathrm{R}$ & $S$ & $S$ & $S$ & $S$ & + & + & $\mathrm{R}$ \\
\hline 100-R-Ec & $\begin{array}{r}\text { Human } \\
\text { (stool; } \\
2015)\end{array}$ & $\begin{array}{l}\text { TEM- } \\
1 \\
(m c r \\
-1- \\
\text { posit } \\
\text { ive) }\end{array}$ & $\begin{array}{l}\text { ST1 } \\
0\end{array}$ & $S$ & $S$ & $\mathrm{R}$ & $S$ & $R$ & + & + & $\mathrm{R}$ \\
\hline MSA899 & $\begin{array}{l}\text { Poultry } \\
\text { (cloaca } \\
\text { I; } \\
2010- \\
2011 \text { ) }\end{array}$ & $\begin{array}{c}\text { SHV- } \\
12\end{array}$ & $\begin{array}{c}S T 2 \\
1\end{array}$ & 1 & $S$ & 1 & $S$ & $S$ & $\mathrm{R}$ & $\mathrm{R}$ & $\mathrm{R}$ \\
\hline $3 A$ & $\begin{array}{l}\text { Chicken } \\
\text { meat } \\
(2012)\end{array}$ & $\begin{array}{l}\text { SHV- } \\
12\end{array}$ & $\begin{array}{r}\text { ST1 } \\
55\end{array}$ & $\mathrm{R}$ & $S$ & $S$ & $S$ & $S$ & $\mathrm{R}$ & $\mathrm{R}$ & $\mathrm{R}$ \\
\hline $15 \mathrm{~A}$ & $\begin{array}{c}\text { Chicken } \\
\text { meat } \\
(2012)\end{array}$ & $\begin{array}{l}\text { SHV- } \\
12\end{array}$ & $\begin{array}{r}\text { ST1 } \\
55\end{array}$ & $\mathrm{R}$ & $S$ & $S$ & $S$ & $S$ & $\mathrm{R}$ & $\mathrm{R}$ & $\mathrm{R}$ \\
\hline
\end{tabular}




\begin{tabular}{|c|c|c|c|c|c|c|c|c|c|c|c|}
\hline 2390300 & $\begin{array}{l}\text { Human } \\
\text { (wound } \\
\text {; 2015) }\end{array}$ & $\begin{array}{c}\text { CMY- } \\
2\end{array}$ & $\begin{array}{c}\text { ST1 } \\
31\end{array}$ & I & $S$ & $S$ & $S$ & $S$ & + & + & $\mathrm{R}$ \\
\hline 2402500 & $\begin{array}{l}\text { Human } \\
\text { (respir } \\
\text { atory; } \\
\text { 2015) }\end{array}$ & $\begin{array}{c}\text { CMY- } \\
33\end{array}$ & $\begin{array}{r}\text { ST1 } \\
31\end{array}$ & $\mathrm{R}$ & $S$ & $S$ & $S$ & $S$ & ++ & +++ & $\mathrm{R}$ \\
\hline MSA1088 & $\begin{array}{l}\text { Poultry } \\
\text { (cloaca } \\
\text { I; } \\
2010 \text { - } \\
2011 \text { ) }\end{array}$ & $\begin{array}{l}\text { CMY- } \\
2\end{array}$ & $\begin{array}{c}\text { ST3 } \\
8\end{array}$ & $\mathrm{R}$ & $S$ & 1 & $S$ & $S$ & + & + & $\mathrm{R}$ \\
\hline MSA970 & $\begin{array}{l}\text { Poultry } \\
\text { (cloaca } \\
\text { I; } \\
2010 \text { - } \\
2011 \text { ) }\end{array}$ & $\begin{array}{l}\text { CMY- } \\
2\end{array}$ & $\begin{array}{c}\text { ST4 } \\
20\end{array}$ & $\mathrm{R}$ & $S$ & 1 & $S$ & $S$ & $\begin{array}{r}++ \\
+\end{array}$ & +++ & $\mathrm{R}$ \\
\hline MSA972 & $\begin{array}{l}\text { Poultry } \\
\text { (cloaca } \\
\text { I; } \\
2010 \text { - } \\
2011 \text { ) }\end{array}$ & $\begin{array}{l}\text { CMY- } \\
2\end{array}$ & $\begin{array}{c}\text { ST4 } \\
20\end{array}$ & $\mathrm{R}$ & $S$ & I & $S$ & $S$ & $\begin{array}{c}++ \\
++\end{array}$ & +++ & + \\
\hline MSA992 & $\begin{array}{l}\text { Poultry } \\
\text { (cloaca } \\
\text { I; } \\
2010- \\
2011 \text { ) }\end{array}$ & $\begin{array}{l}\text { CMY- } \\
2\end{array}$ & $\begin{array}{c}\text { ST4 } \\
20\end{array}$ & $\mathrm{R}$ & $S$ & I & $S$ & $S$ & $\begin{array}{r}++ \\
+\end{array}$ & ++++ & $\mathrm{R}$ \\
\hline
\end{tabular}




\begin{tabular}{|c|c|c|c|c|c|c|c|c|c|c|c|}
\hline $\begin{array}{l}\text { 11/IMD008 } \\
7\end{array}$ & $\begin{array}{l}\text { Poultry } \\
\text { (cloaca } \\
\text { I; } \\
2010 \text { - } \\
2011 \text { ) }\end{array}$ & $\begin{array}{l}\text { CMY- } \\
2\end{array}$ & $\begin{array}{c}\text { ST4 } \\
20\end{array}$ & $\mathrm{R}$ & $S$ & I & $S$ & $S$ & $\begin{array}{r}++ \\
++\end{array}$ & ++++ & $\mathrm{R}$ \\
\hline MSA991 & $\begin{array}{l}\text { Poultry } \\
\text { (cloaca } \\
\text { I; } \\
2010- \\
2011 \text { ) }\end{array}$ & $\begin{array}{l}\text { CMY- } \\
2\end{array}$ & $\begin{array}{r}S T 5 \\
39\end{array}$ & $\mathrm{R}$ & $S$ & 1 & $S$ & $S$ & + & + & $\mathrm{R}$ \\
\hline MSA935 & $\begin{array}{l}\text { Swine } \\
\text { (nose; } \\
2010- \\
2011 \text { ) }\end{array}$ & $\begin{array}{l}\text { CMY- } \\
2\end{array}$ & $\begin{array}{r}S T 5 \\
39\end{array}$ & $\mathrm{R}$ & $S$ & $S$ & S & S & + & + & $\mathrm{R}$ \\
\hline $\begin{array}{l}\text { 11/IMD012 } \\
9\end{array}$ & $\begin{array}{l}\text { Poultry } \\
\text { (cloaca } \\
\text { I; } \\
2010- \\
2011 \text { ) }\end{array}$ & $\begin{array}{l}\text { CMY- } \\
2\end{array}$ & ST9 & $\mathrm{R}$ & $S$ & 1 & $S$ & $S$ & + & + & $\mathrm{R}$ \\
\hline $\begin{array}{l}\text { 11/IMD014 } \\
7\end{array}$ & $\begin{array}{l}\text { Poultry } \\
\text { (cloaca } \\
\text { I; } \\
2010 \text { - } \\
2011 \text { ) }\end{array}$ & $\begin{array}{l}\text { CMY- } \\
2\end{array}$ & $\begin{array}{r}S T 5 \\
27\end{array}$ & $\mathrm{R}$ & $S$ & I & $S$ & $S$ & + & + & $\mathrm{R}$ \\
\hline Sinaj & $\begin{array}{l}\text { Cat } \\
\text { (stool; } \\
\text { 2015) }\end{array}$ & $\begin{array}{l}\text { CMY- } \\
2\end{array}$ & $\begin{array}{c}\text { ST5 } \\
6\end{array}$ & $\mathrm{R}$ & $S$ & $S$ & $S$ & $S$ & $\mathrm{R}$ & + & $\mathrm{R}$ \\
\hline
\end{tabular}




\begin{tabular}{|c|c|c|c|c|c|c|c|c|c|c|c|}
\hline MSA967 & $\begin{array}{l}\text { Swine } \\
\text { (nose; } \\
2010- \\
2011 \text { ) }\end{array}$ & $\begin{array}{c}\text { CMY- } \\
2\end{array}$ & ST2 & $\mathrm{R}$ & $S$ & $\mathrm{R}$ & $\mathrm{S}$ & $S$ & $\mathrm{R}$ & $\mathrm{R}$ & $\mathrm{R}$ \\
\hline MSA969 & $\begin{array}{l}\text { Swine } \\
\text { (nose; } \\
2010- \\
2011 \text { ) }\end{array}$ & $\begin{array}{l}\text { CMY- } \\
2\end{array}$ & $\begin{array}{r}S T 5 \\
32\end{array}$ & $\mathrm{R}$ & $S$ & I & $S$ & $S$ & $\mathrm{R}$ & $\mathrm{R}$ & $\mathrm{R}$ \\
\hline MSA909 & $\begin{array}{l}\text { Poultry } \\
\text { (cloaca } \\
\text { I; } \\
2010- \\
2011 \text { ) }\end{array}$ & $\begin{array}{l}\text { CMY- } \\
\text { 2- } \\
\text { like }\end{array}$ & na & $\mathrm{R}$ & $S$ & $S$ & $S$ & $S$ & $\mathrm{R}$ & $\mathrm{R}$ & $\mathrm{R}$ \\
\hline $1 \mathrm{C}$ & $\begin{array}{c}\text { Turkey } \\
\text { meat } \\
(2012)\end{array}$ & $\begin{array}{l}\text { CMY- } \\
2\end{array}$ & $\begin{array}{r}\text { ST1 } \\
17\end{array}$ & $\mathrm{R}$ & $S$ & $S$ & $S$ & $S$ & + & ++ & $\mathrm{R}$ \\
\hline $13 \mathrm{C}$ & $\begin{array}{l}\text { Chicken } \\
\text { meat } \\
(2012)\end{array}$ & $\begin{array}{l}\text { CMY- } \\
2\end{array}$ & $\begin{array}{c}\text { ST3 } \\
8\end{array}$ & $\mathrm{R}$ & $S$ & $S$ & $S$ & $S$ & $\mathrm{R}$ & + & $\mathrm{R}$ \\
\hline 2081272 & $\begin{array}{l}\text { Human } \\
\text { (blood; } \\
\text { 2012) }\end{array}$ & DHA & na & $S$ & $S$ & $\mathrm{R}$ & $S$ & $S$ & + & ++ & + \\
\hline 73-R Mac & $\begin{array}{l}\text { Human } \\
\text { (stool; } \\
\text { 2015) }\end{array}$ & $\mathrm{DHA}$ & $\begin{array}{c}\text { ST1 } \\
0\end{array}$ & $S$ & $S$ & $S$ & $S$ & $S$ & $\begin{array}{c}++ \\
++\end{array}$ & +++ & $\mathrm{R}$ \\
\hline GC 2919 & $\begin{array}{l}\text { Laborat } \\
\text { ory } \\
\text { strain }\end{array}$ & $\begin{array}{c}\text { ACT- } \\
1\end{array}$ & na & $\mathrm{R}$ & $S$ & $S$ & $S$ & $S$ & $\begin{array}{c}++ \\
++\end{array}$ & +++ & ++++ \\
\hline
\end{tabular}




\begin{tabular}{|c|c|c|c|c|c|c|c|c|c|c|c|}
\hline AH3966 & $\begin{array}{l}\text { Laborat } \\
\text { ory } \\
\text { strain }\end{array}$ & FOX & na & $S$ & $S$ & $S$ & $S$ & $S$ & $\mathrm{R}$ & + & $\mathrm{R}$ \\
\hline 2152061 & $\begin{array}{l}\text { Human } \\
\text { (urine; } \\
\text { 2013) }\end{array}$ & $\begin{array}{l}\text { CTX- } \\
\text { M- } \\
15- \\
\text { /CM } \\
\text { Y-2- } \\
\text { like }\end{array}$ & na & $\mathrm{R}$ & $S$ & $\mathrm{R}$ & $S$ & $S$ & $\mathrm{R}$ & $\mathrm{R}$ & $\mathrm{R}$ \\
\hline $804133 / 14$ & $\begin{array}{l}\text { Human } \\
\text { (stool; } \\
\text { 2014) }\end{array}$ & $\begin{array}{c}\text { CTX- } \\
\text { M- } \\
15 \\
\text { CM } \\
\text { Y-2 }\end{array}$ & $\begin{array}{r}\text { ST1 } \\
17\end{array}$ & $\mathrm{R}$ & $S$ & $S$ & $\mathrm{R}$ & $S$ & + & + & $\mathrm{R}$ \\
\hline 01C60-LF & $\begin{array}{l}\text { Human } \\
\text { (stool; } \\
\text { 2013) }\end{array}$ & $\begin{array}{l}\text { OXA- } \\
48, \\
\text { CTX } \\
-M-9\end{array}$ & na & $\mathrm{R}$ & $S$ & $\mathrm{R}$ & $\mathrm{R}$ & $S$ & $\begin{array}{r}++ \\
+\end{array}$ & ++ & $\mathrm{R}$ \\
\hline 2265478 & $\begin{array}{l}\text { Human } \\
\text { (urine; } \\
\text { 2014) }\end{array}$ & $\begin{array}{c}\text { OXA- } \\
48\end{array}$ & na & $S$ & $S$ & $S$ & $\mathrm{R}$ & $S$ & ++ & + & $\mathrm{R}$ \\
\hline 2058665 & $\begin{array}{l}\text { Human } \\
\text { (na; } \\
\text { 2012) }\end{array}$ & $\begin{array}{l}\text { NDM- } \\
1- \\
\text { /CM } \\
\text { Y-2- } \\
\text { like }\end{array}$ & na & $\mathrm{R}$ & $\mathrm{R}$ & $\mathrm{R}$ & $\mathrm{R}$ & $S$ & + & ++ & $\mathrm{R}$ \\
\hline
\end{tabular}




\begin{tabular}{|c|c|c|c|c|c|c|c|c|c|c|c|}
\hline AC-IT-1 & $\begin{array}{l}\text { Human } \\
\text { (urine; } \\
\text { 2010) }\end{array}$ & $\begin{array}{l}\text { NDM- } \\
1, \\
\text { CTX } \\
-\mathrm{M}- \\
15\end{array}$ & $\begin{array}{c}\text { ST1 } \\
01\end{array}$ & $\mathrm{R}$ & $\mathrm{R}$ & $\mathrm{R}$ & $\mathrm{R}$ & $S$ & $\begin{array}{r}++ \\
+\end{array}$ & ++++ & ++++ \\
\hline 2411192 & $\begin{array}{c}\text { Human } \\
\text { (stool; } \\
\text { 2015) }\end{array}$ & $\begin{array}{l}\text { NDM- } \\
1- \\
\text { /CM } \\
\text { Y-2- } \\
\text { like }\end{array}$ & na & $\mathrm{R}$ & $\mathrm{R}$ & $\mathrm{R}$ & $S$ & $S$ & $\mathrm{R}$ & $\mathrm{R}$ & $\mathrm{R}$ \\
\hline $\begin{array}{l}\text { ATCC } \\
\text { BAA-2452 }\end{array}$ & $\begin{array}{l}\text { Laborat } \\
\text { ory } \\
\text { strain }\end{array}$ & $\begin{array}{l}\text { NDM- } \\
1\end{array}$ & na & $\mathrm{R}$ & $\mathrm{R}$ & $S$ & $\mathrm{R}$ & $S$ & $\mathrm{R}$ & $\mathrm{R}$ & $\mathrm{R}$ \\
\hline DH10B & $\begin{array}{l}\text { Laborat } \\
\text { ory } \\
\text { strain }\end{array}$ & $\begin{array}{l}\text { IMP- } \\
1\end{array}$ & na & $\mathrm{R}$ & $\mathrm{R}$ & $S$ & $S$ & $S$ & $\begin{array}{r}++ \\
+\end{array}$ & +++ & ++++ \\
\hline $\begin{array}{l}\text { 18-M3-Ec- } \\
\text { Col-R }\end{array}$ & $\begin{array}{c}\text { Human } \\
\text { (stool; } \\
\text { 2015) }\end{array}$ & $-{ }^{d}$ & $\begin{array}{c}\text { ST1 } \\
41\end{array}$ & $S$ & $S$ & $S$ & $S$ & $\mathrm{R}$ & + & ++ & $\mathrm{R}$ \\
\hline $\begin{array}{l}26-E c-C o l- \\
R\end{array}$ & $\begin{array}{l}\text { Human } \\
\text { (stool; } \\
\text { 2015) }\end{array}$ & - & $\begin{array}{l}\text { ST6 } \\
9\end{array}$ & $S$ & $S$ & $S$ & $S$ & $\mathrm{R}$ & $\mathrm{R}$ & $\mathrm{R}$ & $\mathrm{R}$ \\
\hline $\begin{array}{l}\text { ATCC } \\
35218\end{array}$ & $\begin{array}{l}\text { Laborat } \\
\text { ory } \\
\text { strain }\end{array}$ & - & na & $S$ & $S$ & $S$ & $S$ & $S$ & + & + & $\mathrm{R}$ \\
\hline
\end{tabular}

ST, sequence type; CTX, cefotaxime; IPM, imipenem; CIP, ciprofloxacin; GEN, gentamicin; COL, colistin, R, resistant; I, intermediate; $\mathrm{S}$, susceptible; na, not available.

${ }^{a}$ Most STs were obtained with the Warwick scheme

(http://enterobase.warwick.ac.uk/species/index/ecoli); those indicated in italic were obtained with the Pasteur scheme (http://bigsdb.web.pasteur.fr/).

${ }^{\mathrm{b}}$ European Committee on Antimicrobial Susceptibility Testing (EUCAST) v.6.0. 
${ }^{\mathrm{c}}$ Strains were defined as susceptible to the bacteriophages when confluent lysis (i.e. complete clearing: ' ++++ '), semiconfluent lysis (i.e. clearing throughout but with faintly hazy background: ' +++ '), opaque lysis (i.e. turbidity throughout the cleared zone: '++') or 'tâches vièrges' (i.e. a few individual clear or opaque plaques: ' + ') was recorded. Strains showing no activity (i.e. no clearing: ' $R$ ') were defined as resistant.

${ }^{d}$ - Indicates no bla genes conferring resistance to extended-spectrum cephalosporins. 


\section{Table 2}

Characteristics of the 21 Proteus mirabilis and 10 Proteus vulgaris strains and their susceptibility to three commercial bacteriophage cocktails

\begin{tabular}{|c|c|c|c|c|c|c|c|c|c|c|}
\hline \multirow[t]{3}{*}{ Strain ID } & \multirow[t]{3}{*}{$\begin{array}{l}\text { Specie } \\
\text { S }\end{array}$} & \multirow{3}{*}{$\begin{array}{l}\text { Origin } \\
\text { (source; } \\
\text { year of } \\
\text { isolatio } \\
\mathrm{n} \text { ) }\end{array}$} & \multirow{3}{*}{$\begin{array}{l}\text { Main } \\
\text { bla } \\
\text { gene } \\
\text { s }\end{array}$} & \multicolumn{4}{|c|}{$\begin{array}{l}\text { Susceptibility } \\
\text { according to } \\
\text { EUCAST }^{\text {a }}\end{array}$} & \multicolumn{3}{|c|}{$\begin{array}{l}\text { Bacteriophage } \\
\text { susceptibility }\end{array}$} \\
\hline & & & & CT & IP & $\mathrm{Cl}$ & GE & PY & INTES & Septapha \\
\hline & & & & $x$ & $M$ & $P$ & $\mathrm{~N}$ & 0 & TI & ge \\
\hline VB1248 & $\begin{array}{l}P . \\
\text { mirab } \\
\text { ilis }\end{array}$ & $\begin{array}{l}\text { Human } \\
\text { (blood; } \\
\text { 2009) }\end{array}$ & $\begin{array}{l}\text { VEB- } \\
6\end{array}$ & $\mathrm{R}$ & $S$ & $\mathrm{R}$ & $\mathrm{R}$ & + & + & +++ \\
\hline $16 \mathrm{~B}$ & $\begin{array}{l}P . \\
\text { mirab } \\
\text { ilis }\end{array}$ & $\begin{array}{c}\text { Turkey } \\
\text { meat } \\
(2012)\end{array}$ & $\begin{array}{l}\text { VEB- } \\
6\end{array}$ & $\mathrm{R}$ & $S$ & $\mathrm{R}$ & $\mathrm{R}$ & ++ & +++ & ++++ \\
\hline 17B & $\begin{array}{l}P . \\
\text { mirab } \\
\text { ilis }\end{array}$ & $\begin{array}{c}\text { Turkey } \\
\text { meat } \\
(2012)\end{array}$ & $\begin{array}{l}\text { VEB- } \\
6\end{array}$ & $\mathrm{R}$ & $S$ & $\mathrm{R}$ & $\mathrm{R}$ & ++ & ++ & ++++ \\
\hline 5705.10 & $\begin{array}{l}P . \\
\text { mirab } \\
\text { ilis }\end{array}$ & $\begin{array}{l}\text { Human } \\
\text { (urine; } \\
\text { 2015) }\end{array}$ & $\begin{array}{l}\text { VEB- } \\
1- \\
\text { like }\end{array}$ & $\mathrm{R}$ & $S$ & $\mathrm{R}$ & I & +++ & +++ & +++ \\
\hline $\begin{array}{l}14091012 \\
74\end{array}$ & $\begin{array}{l}P . \\
\text { mirab } \\
\text { ilis }\end{array}$ & $\begin{array}{l}\text { Human } \\
\text { (na; } \\
\text { 2014) }\end{array}$ & $\begin{array}{l}\text { CTX- } \\
\text { M- } \\
9- \\
\text { like }\end{array}$ & $\mathrm{R}$ & $S$ & na & na & ++ & ++ & $\mathrm{R}$ \\
\hline 5304.28 & $\begin{array}{l}P . \\
\text { mirab } \\
\text { ilis }\end{array}$ & $\begin{array}{c}\text { Human } \\
\text { (urine; } \\
\text { 2013) }\end{array}$ & $\begin{array}{l}\text { TEM } \\
-3- \\
\text { like }\end{array}$ & $\mathrm{R}$ & $S$ & $\mathrm{R}$ & $\mathrm{R}$ & $\mathrm{R}$ & $\mathrm{R}$ & $\mathrm{R}$ \\
\hline
\end{tabular}




\begin{tabular}{|c|c|c|c|c|c|c|c|c|c|c|}
\hline \multirow[t]{2}{*}{ Strain ID } & \multirow[t]{2}{*}{$\begin{array}{l}\text { Specie } \\
\text { s }\end{array}$} & \multirow{2}{*}{$\begin{array}{l}\text { Origin } \\
\text { (source; } \\
\text { year of } \\
\text { isolatio } \\
\mathrm{n} \text { ) }\end{array}$} & \multirow{2}{*}{$\begin{array}{l}\text { Main } \\
\text { bla } \\
\text { gene } \\
\mathrm{s}\end{array}$} & \multicolumn{3}{|c|}{$\begin{array}{l}\text { Susceptibility } \\
\text { according to } \\
\text { EUCAST }^{\text {a }}\end{array}$} & & \multicolumn{3}{|c|}{$\begin{array}{l}\text { Bacteriophage } \\
\text { susceptibility }^{b}\end{array}$} \\
\hline & & & & $\begin{array}{l}\text { CT } \\
x\end{array}$ & $\begin{array}{l}\mathrm{IP} \\
\mathrm{M}\end{array}$ & $\begin{array}{l}\mathrm{Cl} \\
\mathrm{P}\end{array}$ & $\begin{array}{l}\text { GE } \\
N\end{array}$ & $\begin{array}{l}\text { PY } \\
O\end{array}$ & $\begin{array}{l}\text { INTES } \\
\text { TI }\end{array}$ & $\begin{array}{l}\text { Septapha } \\
\text { ge }\end{array}$ \\
\hline 5809.58 & $\begin{array}{l}P . \\
\text { mirab } \\
\text { ilis }\end{array}$ & $\begin{array}{l}\text { Human } \\
\text { (absce } \\
\text { ss; } \\
\text { 2015) }\end{array}$ & $\begin{array}{l}\text { TEM } \\
-3- \\
\text { like }\end{array}$ & $\mathrm{R}$ & $S$ & $\mathrm{R}$ & $\mathrm{R}$ & $\mathrm{R}$ & $\mathrm{R}$ & $\mathrm{R}$ \\
\hline 4810.05 & $\begin{array}{l}P . \\
\text { mirab } \\
\text { ilis }\end{array}$ & $\begin{array}{l}\text { Human } \\
\text { (urine; } \\
\text { 2011) }\end{array}$ & $\begin{array}{c}\text { CMY } \\
-2\end{array}$ & $\mathrm{R}$ & $S$ & I & $S$ & $\mathrm{R}$ & $\mathrm{R}$ & $\mathrm{R}$ \\
\hline 4810.40 & $\begin{array}{l}P . \\
\text { mirab } \\
\text { ilis }\end{array}$ & $\begin{array}{l}\text { Human } \\
\text { (blood; } \\
\text { 2011) }\end{array}$ & $\begin{array}{c}\text { CMY } \\
-2\end{array}$ & $\mathrm{R}$ & $S$ & $\mathrm{R}$ & $S$ & $\mathrm{R}$ & $\mathrm{R}$ & $\mathrm{R}$ \\
\hline 4812.18 & $\begin{array}{l}P . \\
\text { mirab } \\
\text { ilis }\end{array}$ & $\begin{array}{l}\text { Human } \\
\text { (urine; } \\
\text { 2011) }\end{array}$ & $\begin{array}{c}\text { CMY } \\
-2\end{array}$ & $\mathrm{R}$ & $S$ & $\mathrm{R}$ & $S$ & $\mathrm{R}$ & $\mathrm{R}$ & $\mathrm{R}$ \\
\hline 5106.42 & $\begin{array}{l}P . \\
\text { mirab } \\
\text { ilis }\end{array}$ & $\begin{array}{l}\text { Human } \\
\text { (woun } \\
\text { d; } \\
\text { 2012) }\end{array}$ & $\begin{array}{c}\text { CMY } \\
-2\end{array}$ & $\mathrm{R}$ & $S$ & $\mathrm{R}$ & $S$ & $\mathrm{R}$ & $\mathrm{R}$ & $\mathrm{R}$ \\
\hline $\begin{array}{l}\text { 804133- } \\
\text { Nr.6 }\end{array}$ & $\begin{array}{l}P . \\
\text { mirab } \\
\text { ilis }\end{array}$ & $\begin{array}{l}\text { Human } \\
\text { (na; } \\
\text { 2014) }\end{array}$ & $\begin{array}{l}\text { CMY } \\
-2- \\
\text { like }\end{array}$ & $\mathrm{R}$ & $S$ & $\mathrm{R}$ & $\mathrm{R}$ & +++ & +++ & $\mathrm{R}$ \\
\hline $15 \mathrm{D}$ & $\begin{array}{l}P . \\
\text { mirab } \\
\text { ilis }\end{array}$ & $\begin{array}{l}\text { Chicken } \\
\text { meat } \\
(2012)\end{array}$ & $\begin{array}{c}\text { CMY } \\
-2\end{array}$ & 1 & $S$ & $S$ & $S$ & $\mathrm{R}$ & $\mathrm{R}$ & $\mathrm{R}$ \\
\hline
\end{tabular}




\begin{tabular}{|c|c|c|c|c|c|c|c|c|c|c|}
\hline \multirow[t]{2}{*}{ Strain ID } & \multirow[t]{2}{*}{$\begin{array}{l}\text { Specie } \\
\text { s }\end{array}$} & \multirow{2}{*}{$\begin{array}{l}\text { Origin } \\
\text { (source; } \\
\text { year of } \\
\text { isolatio } \\
\text { n) }\end{array}$} & \multirow{2}{*}{$\begin{array}{l}\text { Main } \\
\text { bla } \\
\text { gene } \\
\text { s }\end{array}$} & \multicolumn{4}{|c|}{$\begin{array}{l}\text { Susceptibility } \\
\text { according to } \\
\text { EUCAST }^{\text {a }}\end{array}$} & \multicolumn{3}{|c|}{$\begin{array}{l}\text { Bacteriophage } \\
\text { susceptibility }\end{array}$} \\
\hline & & & & $\begin{array}{l}\text { CT } \\
x\end{array}$ & $\begin{array}{l}\text { IP } \\
M\end{array}$ & $\begin{array}{l}\mathrm{Cl} \\
\mathrm{P}\end{array}$ & $\begin{array}{l}\text { GE } \\
N\end{array}$ & $\begin{array}{l}\text { PY } \\
\text { O }\end{array}$ & $\begin{array}{l}\text { INTES } \\
\text { TI }\end{array}$ & $\begin{array}{l}\text { Septapha } \\
\text { ge }\end{array}$ \\
\hline 5909.63 & $\begin{array}{l}P . \\
\text { mirab } \\
\text { ilis }\end{array}$ & $\begin{array}{l}\text { Human } \\
\text { (urine; } \\
\text { 2015) }\end{array}$ & $\begin{array}{l}\text { CTX- } \\
\text { M- } \\
9- \\
\text { /CM } \\
\text { Y-2- } \\
\text { like }\end{array}$ & $\mathrm{R}$ & $S$ & 1 & $\mathrm{R}$ & $\mathrm{R}$ & $\mathrm{R}$ & $\mathrm{R}$ \\
\hline 6012.36 & $\begin{array}{l}P . \\
\text { mirab } \\
\text { ilis }\end{array}$ & $\begin{array}{l}\text { Human } \\
\text { (stool; } \\
\text { 2016) }\end{array}$ & $\begin{array}{l}\text { NDM } \\
-1- \\
\text { /CM } \\
\text { Y-2- } \\
\text { like }\end{array}$ & $\mathrm{R}$ & $\mathrm{R}$ & $\mathrm{R}$ & $\mathrm{R}$ & $\mathrm{R}$ & $\mathrm{R}$ & $\mathrm{R}$ \\
\hline 6012.61 & $\begin{array}{l}P . \\
\text { mirab } \\
\text { ilis }\end{array}$ & $\begin{array}{l}\text { Human } \\
\text { (blood; } \\
\text { 2016) }\end{array}$ & $-{ }^{c}$ & $S$ & $S$ & $S$ & $S$ & $\mathrm{R}$ & ++ & + \\
\hline 6012.72 & $\begin{array}{l}P . \\
\text { mirab } \\
\text { ilis }\end{array}$ & $\begin{array}{l}\text { Human } \\
\text { (blood; } \\
\text { 2016) }\end{array}$ & - & $S$ & $S$ & $S$ & $S$ & $\mathrm{R}$ & $\mathrm{R}$ & $\mathrm{R}$ \\
\hline 6103.33 & $\begin{array}{l}P . \\
\text { mirab } \\
\text { ilis }\end{array}$ & $\begin{array}{l}\text { Human } \\
\text { (blood; } \\
\text { 2016) }\end{array}$ & - & $S$ & $S$ & $S$ & $S$ & $\mathrm{R}$ & + & $\mathrm{R}$ \\
\hline 6107.51 & $\begin{array}{l}P . \\
\text { mirab } \\
\text { ilis }\end{array}$ & $\begin{array}{l}\text { Human } \\
\text { (blood; } \\
\text { 2016) }\end{array}$ & - & $S$ & $S$ & $S$ & $S$ & $\mathrm{R}$ & $\mathrm{R}$ & $\mathrm{R}$ \\
\hline
\end{tabular}




\begin{tabular}{|c|c|c|c|c|c|c|c|c|c|c|}
\hline \multirow[t]{3}{*}{ Strain ID } & \multirow[t]{3}{*}{$\begin{array}{l}\text { Specie } \\
\text { s }\end{array}$} & \multirow{3}{*}{$\begin{array}{l}\text { Origin } \\
\text { (source; } \\
\text { year of } \\
\text { isolatio } \\
\mathrm{n} \text { ) }\end{array}$} & \multirow{3}{*}{$\begin{array}{l}\text { Main } \\
\text { bla } \\
\text { gene } \\
\text { s }\end{array}$} & \multicolumn{3}{|c|}{$\begin{array}{l}\text { Susceptibility } \\
\text { according to } \\
\text { EUCAST }^{\text {a }}\end{array}$} & & \multicolumn{3}{|c|}{$\begin{array}{l}\text { Bacteriophage } \\
\text { susceptibility }\end{array}$} \\
\hline & & & & CT & IP & $\mathrm{Cl}$ & GE & $P Y$ & INTES & Septapha \\
\hline & & & & $x$ & $M$ & $P$ & $\mathrm{~N}$ & 0 & $\mathrm{TI}$ & ge \\
\hline 6202.32 & $\begin{array}{l}P . \\
\text { mirab } \\
\text { ilis }\end{array}$ & $\begin{array}{l}\text { Human } \\
\text { (blood; } \\
\text { 2016) }\end{array}$ & - & $\mathrm{S}$ & $\mathrm{S}$ & $S$ & $S$ & +++ & ++++ & +++ \\
\hline 6204.01 & $\begin{array}{l}P . \\
\text { mirab } \\
\text { ilis }\end{array}$ & $\begin{array}{l}\text { Human } \\
\text { (blood; } \\
\text { 2016) }\end{array}$ & - & S & $S$ & $S$ & S & $\mathrm{R}$ & + & $\mathrm{R}$ \\
\hline 5307.35 & $\begin{array}{l}P . \\
\text { vulga } \\
\text { ris }\end{array}$ & $\begin{array}{l}\text { Human } \\
\text { (blood; } \\
\text { 2013) }\end{array}$ & - & $S$ & $S$ & $S$ & $S$ & $\mathrm{R}$ & $\mathrm{R}$ & $\mathrm{R}$ \\
\hline 5307.79 & $\begin{array}{l}P . \\
\text { vulga } \\
\text { ris }\end{array}$ & $\begin{array}{l}\text { Human } \\
\text { (blood; } \\
\text { 2013) }\end{array}$ & - & S & $S$ & $S$ & $S$ & $\mathrm{R}$ & $\mathrm{R}$ & $\mathrm{R}$ \\
\hline 5408.26 & $\begin{array}{l}P . \\
\text { vulga } \\
\text { ris }\end{array}$ & $\begin{array}{l}\text { Human } \\
\text { (blood; } \\
\text { 2014) }\end{array}$ & - & $S$ & $S$ & $S$ & $S$ & $\mathrm{R}$ & $\mathrm{R}$ & $\mathrm{R}$ \\
\hline 5410.37 & $\begin{array}{l}P . \\
\text { vulga } \\
\text { ris }\end{array}$ & $\begin{array}{l}\text { Human } \\
\text { (blood; } \\
\text { 2014) }\end{array}$ & - & $S$ & $S$ & $S$ & $S$ & $\mathrm{R}$ & $\mathrm{R}$ & $\mathrm{R}$ \\
\hline 5502.26 & $\begin{array}{l}P . \\
\text { vulga } \\
\text { ris }\end{array}$ & $\begin{array}{l}\text { Human } \\
\text { (blood; } \\
\text { 2014) }\end{array}$ & - & $S$ & $S$ & $S$ & $S$ & $\mathrm{R}$ & $\mathrm{R}$ & $\mathrm{R}$ \\
\hline 5507.56 & $\begin{array}{l}P . \\
\text { vulga } \\
\text { ris }\end{array}$ & $\begin{array}{l}\text { Human } \\
\text { (blood; } \\
\text { 2014) }\end{array}$ & - & $S$ & $S$ & $S$ & $S$ & $\mathrm{R}$ & $\mathrm{R}$ & $\mathrm{R}$ \\
\hline
\end{tabular}




\begin{tabular}{|c|c|c|c|c|c|c|c|c|c|c|}
\hline \multirow[t]{3}{*}{ Strain ID } & \multirow[t]{3}{*}{$\begin{array}{l}\text { Specie } \\
\text { s }\end{array}$} & \multirow{3}{*}{$\begin{array}{l}\text { Origin } \\
\text { (source; } \\
\text { year of } \\
\text { isolatio } \\
\text { n) }\end{array}$} & \multirow{3}{*}{$\begin{array}{l}\text { Main } \\
\text { bla } \\
\text { gene } \\
\text { s }\end{array}$} & \multicolumn{4}{|c|}{$\begin{array}{l}\text { Susceptibility } \\
\text { according to } \\
\text { EUCAST }^{\text {a }}\end{array}$} & \multicolumn{3}{|c|}{$\begin{array}{l}\text { Bacteriophage } \\
\text { susceptibility }\end{array}$} \\
\hline & & & & $\overline{C T}$ & $\mathrm{IP}$ & $\mathrm{Cl}$ & GE & PY & INTES & Septapha \\
\hline & & & & $x$ & $M$ & $P$ & $\mathrm{~N}$ & 0 & TI & ge \\
\hline 5801.02 & $\begin{array}{l}P . \\
\text { vulga } \\
\text { ris }\end{array}$ & $\begin{array}{l}\text { Human } \\
\text { (blood; } \\
\text { 2015) }\end{array}$ & - & $S$ & $S$ & $S$ & $S$ & $\mathrm{R}$ & $\mathrm{R}$ & $\mathrm{R}$ \\
\hline 5906.65 & $\begin{array}{l}P . \\
\text { vulga } \\
\text { ris }\end{array}$ & $\begin{array}{l}\text { Human } \\
\text { (blood; } \\
\text { 2015) }\end{array}$ & - & S & $S$ & $S$ & $S$ & $\mathrm{R}$ & $\mathrm{R}$ & $\mathrm{R}$ \\
\hline 6202.78 & $\begin{array}{l}P . \\
\text { vulga } \\
\text { ris }\end{array}$ & $\begin{array}{l}\text { Human } \\
\text { (urine; } \\
\text { 2016) }\end{array}$ & - & $S$ & $S$ & $S$ & $S$ & ++ & ++ & $\mathrm{R}$ \\
\hline 6208.26 & $\begin{array}{l}P . \\
\text { vulga } \\
\text { ris }\end{array}$ & $\begin{array}{l}\text { Human } \\
\text { (blood; } \\
\text { 2016) }\end{array}$ & - & $S$ & $S$ & $S$ & $S$ & + & + & $R$ \\
\hline
\end{tabular}

CTX, cefotaxime; IPM, imipenem; CIP, ciprofloxacin; GEN, gentamicin; R, resistant; I, intermediate; S, susceptible; na, not available.

Proteus spp. is naturally resistant to colistin.

${ }^{a}$ European Committee on Antimicrobial Susceptibility Testing (EUCAST) v.6.0.

${ }^{b}$ Strains were defined as susceptible to the bacteriophages when confluent lysis (i.e. complete clearing:

'++++'), semiconfluent lysis (i.e. clearing throughout but with faintly hazy background: ' +++ '), opaque lysis (i.e. turbidity throughout the cleared zone: '++') and 'tâches vièrges"' (i.e. a few individual clear or opaque plaques: ' + ') was recorded. Strains showing no activity (i.e. no clearing: ' $R$ ') were defined as resistant.

${ }^{c}$ - Indicates no bla genes conferring resistance to extended-spectrum cephalosporins. 


\section{Table 3}

Summary of the susceptibility of the Escherichia coli and Proteus spp. strains to three commercial bacteriophage cocktails

\begin{tabular}{|c|c|c|c|c|c|}
\hline \multirow[t]{2}{*}{ Phage cocktail/strain group } & \multicolumn{5}{|c|}{ Results of the spot test (\%) ${ }^{a}$} \\
\hline & $\mathrm{R}$ & + & ++ & +++ & ++++ \\
\hline \multicolumn{6}{|l|}{ PYO Bacteriophage (Eliava) } \\
\hline Overall strains $(n=101)$ & 48.5 & 25.7 & 9.9 & 9.9 & 5.9 \\
\hline E. coli $(n=70)$ & 38.6 & 34.3 & 8.6 & 10.0 & 8.6 \\
\hline Only ESBLs $(n=37)$ & 45.9 & 32.4 & 10.8 & 5.4 & 5.4 \\
\hline Only pAmpCs $(n=21)$ & 28.6 & 38.1 & 4.7 & 9.5 & 19.0 \\
\hline Carbapenemases $(n=7)$ & 28.6 & 14.3 & 14.3 & 42.8 & 0 \\
\hline ST131 or ST648 $(n=7)$ & 28.6 & 14.3 & 28.6 & 14.3 & 14.3 \\
\hline Proteus spp. (overall, $n=31$ ) & 70.9 & 6.4 & 12.9 & 9.7 & 0 \\
\hline Proteus mirabilis $(n=21)$ & 66.7 & 4.7 & 14.3 & 14.3 & 0 \\
\hline $\operatorname{MDR}(n=15)^{\mathrm{b}}$ & 60.0 & 6.7 & 20.0 & 13.3 & 0 \\
\hline Proteus vulgaris $(n=10)$ & 80.0 & 10.0 & 10.0 & 0 & 0 \\
\hline \multicolumn{6}{|l|}{ INTESTI Bacteriophage (Eliava) } \\
\hline Overall strains $(n=101)$ & 41.6 & 30.7 & 9.9 & 11.8 & 5.9 \\
\hline E. coli $(n=70)$ & 32.8 & 38.6 & 8.6 & 12.8 & 7.1 \\
\hline Only ESBLs $(n=37)$ & 43.2 & 40.5 & 2.7 & 8.1 & 5.4 \\
\hline Only pAmpCs $(n=21)$ & 14.3 & 42.8 & 9.5 & 23.8 & 9.5 \\
\hline Carbapenemases $(n=7)$ & 28.6 & 14.3 & 28.6 & 14.3 & 14.3 \\
\hline ST131 or ST648 $(n=7)$ & 28.6 & 14.3 & 14.3 & 42.8 & 0 \\
\hline Proteus spp. (overall, $n=31$ ) & 61.3 & 12.9 & 12.9 & 9.7 & 3.2 \\
\hline P. mirabilis $(n=21)$ & 52.4 & 14.3 & 14.3 & 14.3 & 4.7 \\
\hline $\operatorname{MDR}(n=15)^{\mathrm{b}}$ & 60.0 & 6.7 & 13.3 & 20.0 & 0 \\
\hline P. vulgaris $(n=10)$ & 80.0 & 10.0 & 10.0 & 0 & 0 \\
\hline \multicolumn{6}{|l|}{ Septaphage (Biochimpharm) } \\
\hline Overall strains $(n=101)$ & 88.1 & 2.9 & 0 & 2.9 & 5.9 \\
\hline E. coli $(n=70)$ & 91.4 & 2.8 & 0 & 0 & 5.7 \\
\hline
\end{tabular}




\begin{tabular}{llllll}
\hline Only ESBLs $(n=37)$ & 97.3 & 0 & 0 & 0 & 2.7 \\
Only pAmpCs $(n=21)$ & 85.7 & 9.5 & 0 & 0 & 4.7 \\
Carbapenemases $(n=7)$ & 71.4 & 0 & 0 & 0 & 28.6 \\
ST131 or ST648 $(n=7)$ & 100 & 0 & 0 & 0 & 0 \\
Proteus spp. (overall, $n=31)$ & 80.6 & 3.2 & 0 & 9.7 & 6.4 \\
P. mirabilis $(n=21)$ & 71.4 & 4.7 & 0 & 14.3 & 9.5 \\
MDR $(n=15)$ b & 73.3 & 0 & 0 & 13.3 & 13.3 \\
P. vulgaris $(n=10)$ & 100 & 0 & 0 & 0 & 0 \\
\hline
\end{tabular}

ESBL, extended-spectrum $\beta$-lactamase; $\mathrm{pAmpC}$, plasmid-mediated AmpC $\beta$-lactamase; MDR, multidrugresistant.

${ }^{\text {a }}$ Strains were defined as susceptible to the bacteriophages when confluent lysis (i.e. complete clearing: ' ++++ '), semiconfluent lysis (i.e. clearing throughout but with faintly hazy background: ' +++ '), opaque lysis (i.e. turbidity throughout the cleared zone: '++') or 'tâches vièrges' (i.e. a few individual clear or opaque plaques: ' + ') was recorded. Strains showing no activity (i.e. no clearing: ' $R$ ') were defined as resistant.

${ }^{\mathrm{b}}$ Including 7 ESBL-producers, 6 pAmpC-producers, 1 with CTX-M-9-/CMY-2-like and 1 carbapenemase (NDM)-producer.

[41] 